\title{
SISTEM PENDUKUNG KEPUTUSAN PEMILIHAN DOSEN TETAP DENGAN METODE PROFIL MATCHING PADA UNIVERSITAS SERANG RAYA
}

\author{
Iqbal Fernando ${ }^{1}$,Rudianto ${ }^{2}$, Ramdani Budiman ${ }^{3}$ \\ Fakultas teknik informatika universitas Banten jaya \\ iqbal.28nando@gmail.com ,rudianto@unbaja.ac.id , \\ ramdani.budiman@unbaja.ac.id
}

\begin{abstract}
ABSTRAK
Universitas meningkatkan kualitas pembelajaran sepatutnya didukung oleh sumber daya pendidik yang memadai sesuai dengan kebutuhan saat ini. Pemenuhan kebutuhan dosen sesuai dengan kebutuhan juga dituangakan dalam peraturan menristek dikti nomo 2 tahun 2016 tentang registrasi pendidik pada perguruan tinggi. Untuk itu universitas serang raya perlu melakukan langkah-langkah nyata dalam pemenuhan kebutuhan dosen terutama dosen tetap. Akan tetapi hal ini tidaklah dirasa mudah karna seleksi harus dilakukan untuk menyaring dosen-dosen dengan kompetensi yang dibutuhkan saat ini, berdasarkan kriteria-kriteria tertentu. system pendukung keputusan merupakan mekanisme untuk memutuskan atau memilih dari banyaknya alternative berdasarkan kriteria-kriteria yang sudah ditentukan. Metode profil matching merupakan salah satu metode dalam system penudukung keputusan. Prosesnya adalah dengan mengolah data-data calon dosen tetap dengan mencari nilai gap, kemudian akan diberikan bobot. Langkah selanjutnya adalah mencari core factor dan secondary factor, kemudian dihitung nilait totalnya dan kemudian dicari rangking dengan melihat skala prioritas dan kriteria. Dengan adanya system ini diharapkan dapat menunjang dan menjadi alternative solusi untuk menentukan atau memilih dosen tetap dengan cepat dan akurat dimasa yang akan datang.
\end{abstract}

Kata Kunci : system pendukung keputusan, profil matching

Universities improve the quality of learning should be supported by adequate educator resources according to the current needs. Fulfilling the needs of lecturers in accordance with the needs also be written in the rules of Menristek Dikti Nomo 2 years 2016 about the registration of educators on College. Therefore, the University of Serang has to do concrete measures in fulfilling the needs of lecturers, especially lecturers. However, this is not as easy as the selection should be done to filter the lecturers with the competencies needed today, based on certain criteria. Decision support System is a mechanism to decide or choose from the number of alternative based on the criteria that have been determined. The matching profile method is one of the methods in the decision-making system. The process is to process the data of the prospective lecturers still by looking for the gap value, then will be given weights. The next step is to look for the core factor and secondary factor, then calculate the total nilait and then search rankings by looking at the scale of priorities and criteria. With this system is expected to support and become an alternative solution to determine or choose a permanent lecturer quickly and accurately in the future.

KeyWords : Decision support system, matching profile

\section{Pendahuluan}

Dalam Undang-Undang 2 tahun 1989, pasal 16 ayat1 perguruan tinggi merupakan kelanjutan pendidikan menengah yang diselenggarakan untuk mempersiapkan peserta didik untuk menjadi anggota masyarakat yang memiliki kemampuan akademis dan profesional yang dapat menerapkan, mengembangkan dan menciptakan ilmu pengetahuan, teknologi dan kesenian. Perguruan tinggi adalah salah satu lembaga pendidikan yang dibuat pemerintah untuk mencetak sumber daya

manusia yang bekualitas dengan harapan bahwa mereka dapat memajukan bangsa ini. Dengan tujuan pendirian seperti itu maka manajemen perguruan tinggi harus mampu mengelola sumber daya manusia yang dimilikinya dengan sebaik mungkin.sehingga pada saatnya dapat meluluskan mahasiswa-mahasiswa yang benar-benar berkualitas bukan hanya sekedar mendapatkan gelar dan ijasah. Setelah lembaga pendidikan, yang paling berperan penting adalah tenaga pendidik dan tenaga kependidikannya. 
Dengan pertimbangan tersebut Dalam rangka meningkatkan kualitas pendidikan perguruan tinggi Universitas Serang Raya (UNSERA) perlu memperhatikan sumber daya manusia terlebih khusus mengenai tenaga pengajar yaitu dosen. Dosen merupakan pendidik professional dan ilmuan dengan tugas utama mentransformasikan, mengembangkan, dan menyebarluaskan ilmu pengetahuan melalui pendidikan, penelitian, dan pengabdian kepada masyarakat (Undang-udang No. 15 tahun 2005 pasal 1 ayat 2). Dengan keilmuan yang dimiliki dapat menjadikan anak didiknya menjadi orang cerdas dan memiliki wawasan yang luas (Djamarah, 2006). Adapun tugas dan tanggung jawab dosen adalah mengajar dan mendidik yang meliputi memberikan kuliah, praktikum, pelatihan dan evaluasi atau ujian serta tugas pembelajaran lainnya kepada mahasiswa, sesuai dengan jenjang jabatan akademik dosen yang bersangkutan. Selain mengajar dan mendidik dosen melakukan penelitian dan pengabdian kepada masyarakat. Berdasarkan Standard Operating Procedure (SOP) Yayasan Pendidikan Informatika proses seleksi penerimaan dosen tetap di lingkungan Universitas Serang Raya meliputi beberapa proses, 1. Seleksi administrasi, dengan memeriksa kelengkapan berkas pelamar baik persyaratan umum dan persyaratan khusus sesuai dengan yang telah ditetapkan oleh panitia penerimaan dosen tetap dan bagi calon dosen yang tidak lulus seleksi maka tidak berhak untuk melanjutkan proses selanjutnya. 2. Test Potensi Akademi (TPA), test yang terdiri dari 100 buah soal yang harus dikerjakan oleh calon dosen tetap selama $\geq 100$ menit, tes potensi akademik sendiri memiliki beberapa item diantaranya mengenai Logika, Daya Nalar, Hitungan, dan Bahasa Inggris. 3. Test Micro Teaching, tes yang dilakukan untuk menguji kemampuan para calon dosen tetap dalam menyampaikan materi di dalam kelas yang diuji oleh tim micro teaching penerimaan dosen tetap dengan melibatkan pimpinan fakultas (dekan) dan ketua program studi. Adapun item yang dinilai dalam proses micro teaching, kemampuan membuka perkuliahan, sikap dalam proses pembelajaran, penguasaan bahan ajar, proses pembelajaran, menggunakan media, kemapuan menutup perkuliahan. 4. Psikotes, merupakan tes psikologi yang dilakukan oleh tim yang di undang secara khusus oleh panitia penerimaan dosen tetap untuk mengukur aspek individu secara psikis, dan instrument penilaiannya meliputi, aspek kecerdasan, aspek sikap dan cara kerja, aspek kepribadian. 5. Interview, merupakan tes akhir yang dilakukan oleh tim interviewer caln dosen tetap yang melibat kan Wakil Rektor dan Biro Kepegawaian. Interview dilakukan dengan menggunakan beberapa item pedoman penilaian yaitu, penddikan formal, pengalaman kerja, pengetahuan teknik, keterampilan teknik, motivasi, kerjasama, etika (sopan santun), kemampuan komunikasi, kemampuan bahasa asing dan penampilan diri.

Sistem Pendukung Keputusan atau dikenal dengan Decision Support System (DSS) merupakan sistem informasi interaktif yang menyediakan informasi, pemodelan, dan pemanipulasian data. Sistem itu digunakan untuk membantu pengambilan keputusan dalam situasi yang semiterstruktur dan situasi yang tidak terstruktur, dimana tidak seorang pun tahu secara pasti bagaimana keputusan seharusnya dibuat. (Alter, 2002, dalam Kusrini, 2007).

Tidak adanya pengolahan data yang lebih baik terhadap penentuan dosen tetap yang telah dilaksanakan, menjadikan pihak bagian SDM/kepegawaian tidak bisa memberikan hasil yang maksimal tentang siapa saja yang bisa di tetapkan sebagai dosen tetap. Sementara di sisi yang lain memerlukan suatu sistem pendukung keputusan untuk penentuan dosen tetap. Pengambilan keputusan merupakan aktivitas utama manajemen yang sangat menentukan keberadaan suatu organisasi. Karena pentingnya aktifitas ini maka para ahli manajemen senantiasa mencari sistem, metode dan teknologi yang dapat membantu manajemen dalam melaksanakan tugas tersebut.

Salah satu metode penentuan dosen tetap adalah dengan menggunakan metode profile matching dimana metode ini merupakan salah satu metode dalam memecahkan permasalahan yang memberikan perangkingan kepada kandidat terbaik dari kriteria-kriteria yang telah dipetakan. Profile Matching merupakan suatu proses yang sangat penting dalam manajemen Sumber Daya Manusia (SDM) dimana terlebih dahulu ditentukan kompetensi (kemampuan) yang diperlukan untuk menentukan siapa calon dosen yang akan dipilih menjadi dosen tetap. Dalam proses Profile Matching secara garis besar merupakan proses membandingkan antara kompetensi individu kedalam kompetensi jabatan sehingga dapat diketahui perbedaan kompetensinya (disebut juga GAP), semakin kecil gap yang dihasilkan maka bobot nilainya semakin besar berarti memiliki peluang lebih besar untuk calon dosen menempati posisi tersebut. (Rahma. 2003).

Hasil akhir dari penelitian ini adalah sebuah sistem pendukung keputusan (SPK) yang dilengkapi dengan pengolahan data yang lebih akurat. Sistem pendukung keputusan yang dihasilkan sebagai alat bantu untuk penentuan dosen tetap.

\section{Landasan Teori}

\section{SistemPendukung Keputusan}

Konsep Decision Support System pertama kali dinyatakan oleh Michael S. Scott Morton pada tahun 1970 dengan istilah "Management Decision 
System" (Sprague and Watson: 1993: 4) (Turban: 1995). Setelah pernyataan tersebut, beberapa perusahaan dan perguruan tinggi melakukan riset dan mengembangkan konsep Decision Support System. Decision Support System pada dasarnya dirancang untuk mendukung seluruh tahap pengambilan keputusan mulai dari mengidentifikasi masa,lah, memilih data yang relevan, menentukan pendekatan yang digunakan dalam proses pengambil keputusan, sampai pemilihan alternative.

Sprague dan Watson mendefinisikan Sistem Pendukung Keputusan (SPK) sebagai sistem yang memiliki lima karakteristik utama yaitu (Sprague et.al, 1993):

1. Sistem yang berbasis computer.

2. Dipergunakan untuk membantu para pengambil keputusan.

3. Untuk memecahkan masalah-masalah rumit yang mustahil dilakukan dengan kalkulasi manual.

4. Melalui cara simulasi yang interaktif.

5. Dimana data dan model analisis sebagai komponen utama.

Sistem Penunjang Keputusan (Decision Support System) merupakan sistem informasi Interkatif yang menyediakan Informasi, pemodelan dan pemanipulasian data. Sistem itu digunakan untuk membantu pengambilan keputusan dalm situasi yang semiterstruktur dan situasi yang tidak terstruktur, dimana tidak seorang pun tahu secara pasti bagaimana keputusan seharusnya dibuat. Menurut (Menurut Alter, 2002 dalam Kusrini, 2007), Sistem Penunjang Keputusan (Decision Support System) adalah sebuah sistem yang memberikan kemudahan seorang mengambil keputusan dengan memeberikan rekomendasi dalm keputusan yang akan diambilnya.

\section{Profil Macthing}

Dalam proses profile matching secara garis besar merupakan proses membandingkan antara nilai data aktual dari suatu profile yang akan dinilai dengan nilai profile yang diharapkan atau dengan pedoman lain melakukan pengambilan keputusan dengan mengasumsikan bahwa terdapat tingkat variabel predictor pada penerimaan dosen yang ideal yang harus dipenuhi untuk diputuskan dalam penerimaan dosen di universitas serang raya (unsera), sehingga dapat diketahui nilai perbedaan kompetensinya (disebut juga gap). Adapun sistem program yang dibuat

adalah software profile matching sebagai alat bantu untuk mempercepat proses matching antara profile jabatan (soft kompetensi jabatan) dengan profile karyawan (soft kompetensi karyawan) sehingga dapat memperoleh informasi lebih cepat, baik untuk mengetahui gap kompetensi antara jabatan dengan pemegang jabatan maupun dalam pemilihan kandidat yang paling sesuai untuk suatu jabatan (ranking kandidat). (Kusrini, 2007).

Profile Matching merupakan suatu proses yang sangat penting dalam manajemen sumber daya manusia (SDM) dimana terlebih dahulu ditentukan kompetensi (kemampuan) yang diperlukan oleh suatu jabatan. Kompetensi kemapuan tersebut haruslah dapat dipenuhi oleh pemegang atau calon yang akan dinilai kinerjanya. Dalam proses profile matching secara garis besar merupakan proses membandingkan antara kompetensi individu kedalam komptensi jabatan sehingga dapat diketahui perbedaan kompetensinya (disebut juga gap). Semakin kecil gap yang dihasilkan maka bobot nilainya semakin besar berarti memiliki pekuang lebih besar untuk karyawan menempati posisi tersebut (Rahma. 2003:101).

Model matematika GAP atau Profile Matching merupakan sebuah metode untuk membandingkan kriteria-kriteria yang menjadi acuan agar ditemukan nilai dari masing-masing profile yang telah ada. Dalam sistem yang dibangun penulisan menggunakan model matematika GAP dengan mencari selisih GAP dengan membandingkan akumulasi nilai krietria berdasarkan bobot dengan standar nilai qualisifikasi yang ada, dengan hasil berupa memenuhi syarat atau tidak memenuhi.

\section{Pemetaan GAP kompetensi}

Gap : perbedaan/selisih value masing-masing aspek/attribut dengan value target.

Gap = Value Attribut - Value Target
Contoh : Menghitung Gap calon Dosen
Tetap di Perguruan Tinggi :
Gap = profil calon dosen - profil jabatan
kosong.

\section{Pembobotan}

Setelah diperoleh Gap pada masing-masing individu, setiap profile individu diberi bobot nilai sesuai dengan ketentuan pada Tabel Bobot Nilai Gap.

Tabel 2.1 Tabel Bobot Nilai GAP.

\begin{tabular}{|c|c|c|}
\hline Selisih & Bobot Nilai & Keterangan \\
\hline 0 & 5 & Tidak ada selish (kompetensi sesuai dg yg dibutuhkan) \\
\hline 1 & 4,5 & Kompetens individu kelebihan 1 tingkat \\
\hline-1 & 4 & Kompetens individu kekurangan 1 tingkat \\
\hline 2 & 3,5 & Kompetens induvidu kelebihan 2 tingkat \\
\hline$\cdot 2$ & 3 & Kompetens individu kekurangan 2 tingkat \\
\hline 3 & 2,5 & Kompetens indvividu kelebihan 3 tingkat \\
\hline-3 & 2 & Kompetens individu kekurangan 3 tingkat \\
\hline 4 & 1,5 & Kompetens i individu kelebihan 4 tingkat \\
\hline 4 & 1 & Kompetens individu kekurangan 4 tingkat \\
\hline
\end{tabular}

JIKA | 77 
5. Perhitungan dan pengelompokan Core dan Secondary Factor.

Setelah menentukan bobot nilai Gap untuk ketiga aspek, yaitu aspek kecerdasan, sikap kerja, dan perilaku dengan cara yang sama setiap aspek dikelompokan menjadi 2 kelompok yaitu:

\section{a. Core Factor}

Perhitungan Core Factor ditunjukan menggunakan rumusdibawah ini:

$$
N S F=\frac{\sum N S(\text { kriteria })}{\sum I S}
$$

Keterangan :

$$
\begin{array}{ll}
\text { NCF } & \text { : Nilai rata-rata core factor } \\
\text { NC (kriteria) } & : \text { Jumlah total nilai core factor } \\
\text { (Kriteria) } & \\
\text { IC } & \text { : Jumlah item core factor }
\end{array}
$$

\section{b. Secondary Factor}

Perhitungan secondary factor bias ditunjukan dengan rumus berikut:

$$
N S F=\frac{\sum N S(\text { kriteria })}{\sum I S}
$$

Keterangan :

NSF : Nilai rata-rata secondary factor

NS : Jumlah nilai total secondary factor (Kiriteria)

IS : Jumlah item secondary factor

\section{c. Perhitungan Nilai Total}

Selanjutnya perhitungan nilai total berdasar nilai dari core dan secondary factor yang digunakan sebagai kriteria penilaian yang berpengaruh terhadap berhasil atau tidaknya calon dosen tetap dalam tes kompetensi. Perhitungan dapat dilakukan menggunakan persamaan.

$$
N(\text { Tot_kriteria })=(x) \% \text { NCF }+(x) \% \text { NSF }
$$

Keterangan :

NCF : Nilai rata-rata core factor

NSF : Nilai rata-rata secondary factor

$\mathrm{N} \quad$ : Nilai total dari aspek (kriteria)

\section{d. Ranking}

Langkah terakhir adalah perhitungan ranking yang dilakukan dengan persamaan.

$$
\text { Ranking }=(x) \% N 1+(x) \% N 2+(x) \% N n
$$

Keterangan :

e.

$\mathrm{N} 1, \mathrm{~N} 2, \mathrm{Nn} \quad$ : Nilai total per kriteria $\mathrm{f}$.

$(\mathrm{x}) \%$

: Persentase nilai kriteriag.

\section{Metodologi Penelitian}

\subsection{Studi Literatur}

h.

Mempelajari dan mengumpulkan literałure yang berkaitan dengan Decision Support System (DSS) dengan menggunakan metode Profile Miatching baik berupa jurnal, situs-situs internet, dañ buku.

\subsection{Wawancara}

Metode ini dilakukan dengan cara tanya jawab langsung dengan pihak terkait dengan seleksi calon dosen tetap ditempat yang sedang diteliti.

\subsection{Metode Analisis Data}

Dilakukan setelah data dan informasi dari metode literature dan wawancara sudah terkumpul. Setelah itu data dan informasi tersebut dianalisis sesuai dengan permasalahan dalam peneltian ini.

\section{Pembahasan \\ 4.1 penilaian}

Skala ordinal untuk nilai, adalah perbandingan antar kategori sebuah objek yang diberi bobot nilai berbeda adapun skala ordinal untuk penelitian ini adalah :

$$
\begin{aligned}
& 1=\text { Sangat kurang } \\
& 2=\text { Kurang } \\
& 3=\text { Cukup } \\
& 4=\text { Baik } \\
& 5=\text { Sangat Baik }
\end{aligned}
$$

\subsection{Nilai Target}

Nilai target adalah nilai dimana bagian SDM menentukan berapa jumlah nilai yg harus didapat pada proses penentuan dosen tetap dan acuan nilai tersebut ada di penilaian skala ordinal. Adapun nilai target pada aspek-aspek diatas adalah :

a. Aspek Tes Potensi Akademik (TPA) :
1. : Logika 3
2. : Daya Nalar 4
3. : Hitungan 4
4. : Daya bayang 3
5. : Bahasa Inggris 3

b. Aspek Kemampuan Membuka Perkuliahan:

1 : Menarik perhatian mahasiswa 3

2 : Menimbulkan motivasi 4

3 : Memberi acuan bahan ajar yang disajikan 4

4 : Membuat kaitan materi yang lalu dengan materi yang $\mathbf{4}$ akan disajikan.

c. Aspek Intelegensi Umum:

1 : Intelegensi umum 4

2 : Logika dan sistematika berfikir 4

3 : Berfikir kritis 4

4 : Kemampuan menyelesaikan masalah 4

d. Aspek Interview (wawancara)
1. : Pendidikan formal 4
2. : Pengalaman kerja 3
3. : Pengetahuan teknis $\mathbf{3}$
4. : Keterampilan teknis 3
5. : Motivasi 4
6. : Kerjasama 4
7. : Etika 4
8. : Kemampuan komunikasi 4
9. : Kemampuan bahasa asing 4
10. : Penampilan diri 3
11. : Kemampuan memimpin 3 
12. : Pemeriksa referensi 3

Tabel 1. nilai aspek tes potensi akademik

\begin{tabular}{|l|l|l|l|l|l|l|}
\hline No & Alternatif Dosen & $\mathbf{1}$ & $\mathbf{2}$ & $\mathbf{3}$ & $\mathbf{4}$ & $\mathbf{5}$ \\
\hline 1 & CD001 & 2 & 3 & 1 & 1 & 4 \\
\hline 2 & CD002 & 3 & 3 & 2 & 2 & 1 \\
\hline 3 & CD003 & 3 & 3 & 1 & 2 & 1 \\
\hline 4 & CD004 & 1 & 2 & 2 & 3 & 2 \\
\hline 5 & CD005 & 1 & 1 & 3 & 2 & 4 \\
\hline
\end{tabular}

Tabel 2. nilai aspek kemampuan membuka perkuliahan

\begin{tabular}{|l|l|l|l|l|l|}
\hline No & Id_dosen & $\mathbf{1}$ & $\mathbf{2}$ & $\mathbf{3}$ & $\mathbf{4}$ \\
\hline 1 & CD001 & 4 & 3 & 3 & 4 \\
\hline 2 & CD002 & 4 & 3 & 3 & 4 \\
\hline 3 & CD003 & 4 & 3 & 3 & 3 \\
\hline 4 & CD004 & 4 & 4 & 3 & 3 \\
\hline 5 & CD005 & 3 & 3 & 3 & 3 \\
\hline
\end{tabular}

Tabel 3. Nilai aspek intelegensia

\begin{tabular}{|l|l|l|l|l|l|}
\hline No & Id_dosen & $\mathbf{1}$ & $\mathbf{2}$ & $\mathbf{3}$ & $\mathbf{4}$ \\
\hline 1 & CD001 & 3 & 3 & 3 & 3 \\
\hline 2 & CD002 & 3 & 3 & 3 & 3 \\
\hline 3 & CD003 & 4 & 4 & 4 & 4 \\
\hline 4 & CD004 & 3 & 3 & 3 & 3 \\
\hline 5 & CD005 & 4 & 4 & 4 & 4 \\
\hline
\end{tabular}

Tabel 4. Nilai aspek wawancara

\begin{tabular}{|l|l|l|l|l|l|l|l|l|l|l|l|l|l|}
\hline $\begin{array}{l}\mathbf{N} \\
\mathbf{0}\end{array}$ & $\begin{array}{l}\text { Id_d } \\
\text { ose } \\
\mathbf{n}\end{array}$ & $\mathbf{1}$ & $\mathbf{2}$ & $\mathbf{3}$ & $\mathbf{4}$ & $\mathbf{5}$ & $\mathbf{6}$ & $\mathbf{7}$ & $\mathbf{8}$ & $\mathbf{9}$ & $\mathbf{1}$ & $\mathbf{1}$ & $\mathbf{1}$ \\
$\mathbf{0}$ & $\mathbf{1}$ & $\mathbf{2}$ \\
\hline 1 & $\begin{array}{l}\mathrm{CD} 0 \\
01\end{array}$ & 4 & 4 & 4 & 3 & 3 & 3 & 4 & 4 & 4 & 4 & 4 & 4 \\
\hline 2 & $\begin{array}{l}\mathrm{CD} 0 \\
02\end{array}$ & 4 & 3 & 4 & 4 & 3 & 3 & 4 & 4 & 3 & 4 & 4 & 4 \\
\hline 3 & $\begin{array}{l}\mathrm{CD} 0 \\
03\end{array}$ & 4 & 3 & 4 & 4 & 3 & 3 & 4 & 4 & 3 & 4 & 4 & 4 \\
\hline 4 & $\begin{array}{l}\mathrm{CD} 0 \\
04\end{array}$ & 3 & 4 & 3 & 3 & 3 & 3 & 3 & 4 & 3 & 4 & 4 & 4 \\
\hline 5 & $\begin{array}{l}\mathrm{CD} 0 \\
05\end{array}$ & 4 & 4 & 3 & 3 & 3 & 4 & 4 & 4 & 3 & 3 & 3 & 0 \\
\hline
\end{tabular}

\subsection{Pemetaan gap}

Gap atau perbedaan / selisih value masing-masing aspek / attribute dengan value target. Rumus untuk menentukan nilai Gap adalah :

Gap $=$ Value attribute - Value Target

keterangan :

Value attribute $=$ nilai skala ordinal

Value target = nilai profil ideal

Hasil perhitunagan dapat dilihat pada table dibawah ini :

Tabel 5. Perhitungan Gap untuk aspek tes potensi akademik

\begin{tabular}{|l|l|l|l|l|l|l|}
\hline No & Id_Dosen & $\mathbf{1}$ & $\mathbf{2}$ & $\mathbf{3}$ & $\mathbf{4}$ & $\mathbf{5}$ \\
\hline 1 & CD001 & 2 & 3 & 1 & 1 & 4 \\
\hline 2 & CD002 & 3 & 3 & 2 & 2 & 1 \\
\hline 3 & CD003 & 3 & 3 & 1 & 2 & 1 \\
\hline 4 & CD004 & 1 & 2 & 2 & 3 & 2 \\
\hline 5 & CD005 & 1 & 1 & 3 & 2 & 4 \\
\hline \hline Profil Ideal & 3 & 4 & 4 & 3 & 3 \\
\hline \hline 1 & CD001 & -1 & -1 & -3 & -2 & 1 \\
\hline 2 & CD002 & 0 & -1 & -2 & -1 & -2 \\
\hline 3 & CD003 & 0 & -1 & -3 & -1 & -2 \\
\hline 4 & CD004 & -2 & -2 & -2 & 0 & -1 \\
\hline 5 & CD005 & -2 & -3 & -1 & -1 & 3 \\
\multirow{2}{*}{}
\end{tabular}

Keterangan :

1. : Logika 3

2. : Daya Nalar 4

3. : Hitungan 4

4. : Daya bayang 3

5. : Bahasa Inggris 3

Tabel 6. Perhitungan Gap untuk aspek kemampuan membuka perkuliahan

\begin{tabular}{|l|l|l|l|l|l|}
\hline No & Id_dosen & 1 & 2 & 3 & 4 \\
\hline 1 & CD001 & 4 & 3 & 3 & 4 \\
\hline 2 & CD002 & 4 & 3 & 3 & 4 \\
\hline 3 & CD003 & 4 & 3 & 3 & 3 \\
\hline 4 & CD004 & 4 & 4 & 3 & 3 \\
\hline 5 & CD005 & 3 & 3 & 3 & 3 \\
\hline \hline Profil Ideal & $\mathbf{3}$ & $\mathbf{3}$ & $\mathbf{3}$ & $\mathbf{3}$ \\
\hline \hline
\end{tabular}




\begin{tabular}{|c|c|c|c|c|c|}
\hline 1 & CD001 & 1 & 0 & 0 & 1 \\
\hline 2 & CD002 & 1 & 0 & 0 & 1 \\
\hline 3 & CD003 & 1 & 0 & 0 & 0 \\
\hline 4 & CD004 & 1 & 1 & 0 & 0 \\
\hline 5 & CD005 & 0 & 0 & 0 & 0 \\
\hline
\end{tabular}

Keterangan :

1 : Menarik perhatian mahasiswa 3

2 : Menimbulkan motivasi 4

3 : Memberi acuan bahan ajar yang disajikan $\mathbf{4}$

4 : Membuat kaitan materi yang lalu dengan materi yang akan disajikan 4

Tabel 7. Perhitungan Gap untuk aspek intelegensi umum

\begin{tabular}{|c|c|c|c|c|c|}
\hline No & Id_Dosen & 1 & 2 & 3 & 4 \\
\hline 1 & CD001 & 3 & 3 & 3 & 3 \\
\hline 2 & CD002 & 3 & 3 & 3 & 3 \\
\hline 3 & CD003 & 4 & 4 & 4 & 4 \\
\hline 4 & CD004 & 3 & 3 & 3 & 3 \\
\hline 5 & CD005 & 4 & 4 & 4 & 4 \\
\hline \multicolumn{2}{|c|}{ Profil Ideal } & 4 & 4 & 4 & 4 \\
\hline 1 & CD001 & -1 & -1 & -1 & -1 \\
\hline 2 & CD002 & -1 & -1 & -1 & -1 \\
\hline 3 & CD003 & 0 & 0 & 0 & 0 \\
\hline 4 & CD004 & -1 & -1 & -1 & -1 \\
\hline 5 & CD005 & 0 & 0 & 0 & 0 \\
\hline
\end{tabular}

Keterangan :

1 : Intelegensi umum 4

2 : Logika dan sistematika berfikir 4

3 : Berfikir kritis 4

4 : Kemampuan menyelesaikan masalah 4

Tabel 8. Perhitungan Gap untuk aspek interview (wawancara)

\begin{tabular}{|l|l|l|l|l|l|l|l|l|l|l|l|l|l|}
\hline $\begin{array}{l}\mathbf{N} \\
\mathbf{o}\end{array}$ & $\begin{array}{l}\text { Id } \\
\text { Do } \\
\text { se } \\
\mathbf{n}\end{array}$ & $\mathbf{1}$ & $\mathbf{2}$ & $\mathbf{3}$ & $\mathbf{4}$ & $\mathbf{5}$ & $\mathbf{6}$ & $\mathbf{7}$ & $\mathbf{8}$ & $\mathbf{9}$ & $\mathbf{1}$ & $\mathbf{1}$ & $\mathbf{1}$ \\
$\mathbf{0}$ & $\mathbf{1}$ & $\mathbf{2}$ \\
\hline 1 & $\begin{array}{l}\mathrm{CD} \\
00 \\
1\end{array}$ & 4 & 4 & 4 & 3 & 3 & 3 & 4 & 4 & 4 & 4 & 4 & 4 \\
\hline & $\begin{array}{l}\mathrm{CD} \\
00\end{array}$ & & & & & & & & & & & & \\
2 & 4 & 3 & 4 & 4 & 3 & 3 & 4 & 4 & 3 & 4 & 4 & 4 \\
\hline
\end{tabular}

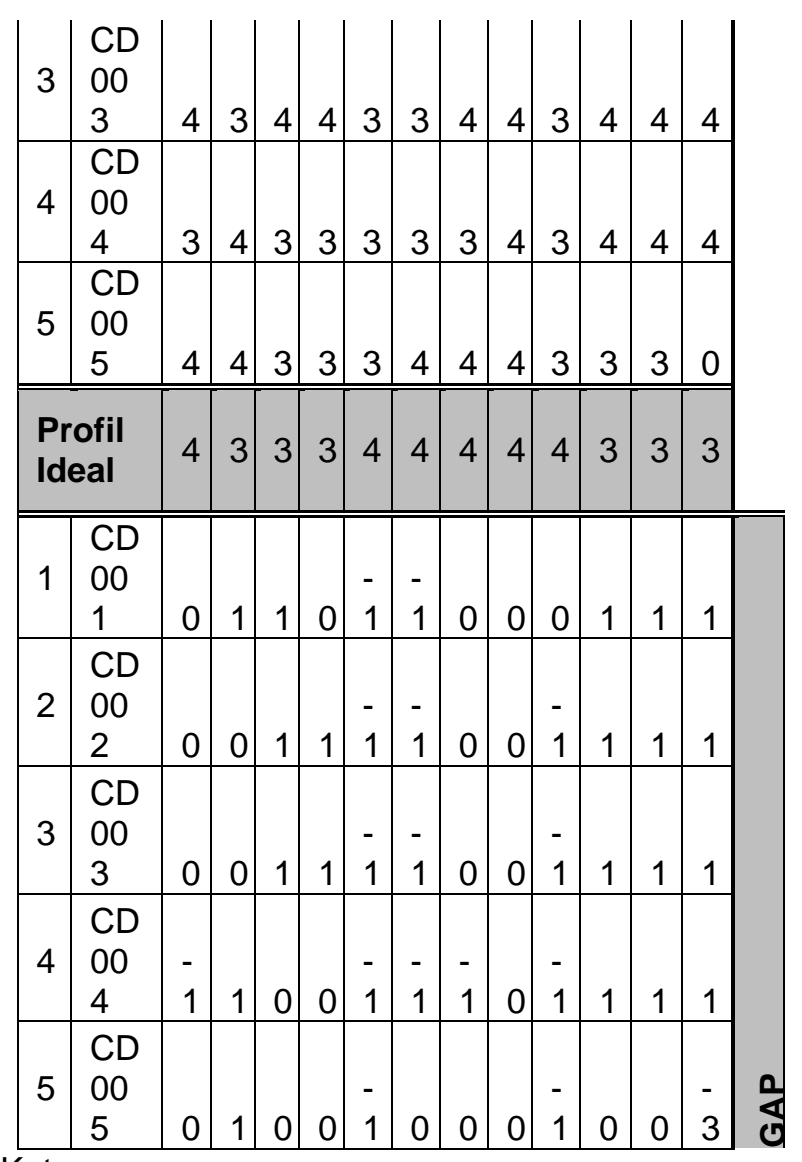

Keterangan :

1. Pendidikan formal 4

2. Pengamalaman kerja 3

3. Pengetahuan teknis 3

4. Keterampilan teknis 3

5. Motivasi 4

6. Kerja sama 4

7. Etika 4

8. Komunikasi 4

9. Bahasa asing 4

10. Penampilan 3

11. Kepemimpinan 3

12. Pemeriksa referensi 3

\subsection{Perhitungan dan pengelompokan core factor dan secondary factor}

Setelah menentukan bobot nilai gap untuk kesebelas aspek dengan cara yang sama, selanjutnya setiap aspek akan dikelompokan menjadi dua kelompok yaitu kelompok core factor dan kelompok secondary factor. Untuk perhitungan core factor dapat ditunjukan dengan rumus :

$$
\mathrm{NCF}=\frac{\sum N C}{\sum I C}
$$

Keterangan :

$\mathrm{NCF}$

NC (aspek) : Jumlah nilai total core factor

IC 
Sedangkan untuk perhitungan Secondary Factor dapat ditunjukan dengan rumus dibawah ini :

$$
\mathrm{NSF}=\frac{\sum N S}{\sum I S}
$$

Keterangan :

NSF : Nilai rata-rata secondary factor

NS (aspek) : Jumlah nilia total secondary factor IS : Jumlah item secondary factor

1. Aspek tes potensi akademik nilai core factor dan secondary factor

Perhitungan dengan terlebih dahulu menentukan sub aspek mana yang menjadi core factor dari aspek tes potensi akademik, sub aspek 1, 3 dan 5, dan sub aspek sisanya akan menjadi secondary factor. Kemudian nilai core factor dan secondary factor tersebut dijumlahkan dan hasilnya bs dilihat pada tabel berikut. Cara pengerjaannya seperti contoh dibawah ini:

$$
\begin{gathered}
\mathrm{CD} 001 \mathrm{NCF}=\frac{4+2+4,5}{3}=2 \\
\mathrm{CD} 001 \mathrm{NSF}=\frac{4+3}{2}=3,5 \\
\mathrm{CD} 002 \mathrm{NCF}=\frac{5+3+3}{3}=3,66 \\
\mathrm{CD} 002 \mathrm{NSF}=\frac{4+4}{2}=4 \\
\mathrm{CD} 003 \mathrm{NCF}=\frac{5+2+3}{3}=3,33 \\
\mathrm{CD} 003 \mathrm{NSF}=\frac{4+4}{2}=4 \\
\mathrm{CD} 004 \mathrm{NCF}=\frac{3+3+4}{3}=3,33 \\
\mathrm{CD} 004 \mathrm{NSF}=\frac{3+5}{2}=4 \\
\mathrm{CD} 005 \mathrm{NCF}=\frac{3+4+2,5}{3}=2,33 \\
\mathrm{CD} 005 \mathrm{NSF}=\frac{2+6}{2}=3
\end{gathered}
$$

Tabel 9 Pengelompokan bobot nilai Gap tes potensi akademik

\begin{tabular}{|l|l|l|l|l|l|l|l|l|}
\hline $\begin{array}{l}\text { N } \\
0\end{array}$ & $\begin{array}{l}\text { Id_Do } \\
\text { sen }\end{array}$ & $\mathbf{1}$ & $\mathbf{2}$ & $\mathbf{3}$ & $\mathbf{4}$ & $\mathbf{5}$ & $\begin{array}{l}\text { Cor } \\
\mathrm{e}\end{array}$ & $\begin{array}{l}\text { Second } \\
\text { ary } \\
\text { Factor }\end{array}$ \\
\hline
\end{tabular}

\begin{tabular}{|l|l|l|l|l|l|l|l|l|}
\hline & & & & & & & $\begin{array}{l}\text { Fac } \\
\text { tor }\end{array}$ & \\
\hline \hline 1 & $\begin{array}{l}\text { CD00 } \\
1\end{array}$ & 4 & 4 & 2 & 3 & 4,5 & 2 & 3.5 \\
\hline 2 & $\begin{array}{l}\text { CD00 } \\
2\end{array}$ & 5 & 4 & 3 & 4 & 3 & 3.66 & 4 \\
\hline 3 & $\begin{array}{l}\text { CD00 } \\
3\end{array}$ & 5 & 4 & 2 & 4 & 3 & 3.33 & 4 \\
\hline 4 & $\begin{array}{l}\text { CD00 } \\
4\end{array}$ & 3 & 3 & 3 & 5 & 4 & 3.33 & 4 \\
\hline 5 & $\begin{array}{l}\text { CD00 } \\
5\end{array}$ & 3 & 2 & 4 & 4 & 2,5 & 2.33 & 3 \\
\hline
\end{tabular}

2. Aspek kemampuan membuka perkuliahan nilai core factor dan secondary factor cara perhitungan sama seperti menghitung CF dan SF pada kriteria tes potensi akademik.adapun hasilnya ditunjukan pada tabel di bawah ini

Tabel 10 Pengelompokan bobot nilai Gap kemampuan membuka perkuliahan

\begin{tabular}{|l|l|l|l|l|l|l|l|}
\hline $\begin{array}{l}\mathbf{N} \\
\mathbf{0}\end{array}$ & $\begin{array}{l}\text { Id_do } \\
\text { sen }\end{array}$ & $\mathbf{1}$ & $\mathbf{2}$ & $\mathbf{3}$ & $\mathbf{4}$ & $\mathbf{C F}$ & $\mathbf{S F}$ \\
\hline \hline 1 & $\begin{array}{l}\text { CD00 } \\
1\end{array}$ & 4,5 & 5 & 5 & 4,5 & 5 & 0 \\
\hline 2 & $\begin{array}{l}\text { CD00 } \\
2\end{array}$ & 4,5 & 5 & 5 & 4,5 & 5 & 0 \\
\hline 3 & $\begin{array}{l}\text { CD00 } \\
3\end{array}$ & 4,5 & 5 & 5 & 5 & 5 & 2.5 \\
\hline 4 & $\begin{array}{l}\text { CD00 } \\
4\end{array}$ & 4,5 & 4,5 & 5 & 5 & 2.5 & 2.5 \\
\hline 5 & $\begin{array}{l}\text { CD00 } \\
5\end{array}$ & 4,5 & 5 & 5 & 5 & 5 & 2.5 \\
\hline
\end{tabular}

3. Aspek intelegensi umum nilai core factor dan secondary factor

Perhitungan dengan terlebih dahulu menentukan sub aspek mana yang menjadi core factor dari aspek intelegensi umum, sub aspek 1 dan 2 sub aspek sisanya akan menjadi secondary factor. Kemudian nilai core factor dan secondary factor tersebut dijumlahkan dan hasilnya bisa dilihat pada tabel berikut.

Tabel 11 Pengelompokan bobot nilai Gap intelegensi umum

\begin{tabular}{|l|l|l|l|l|l|l|l|}
\hline $\begin{array}{l}\text { N } \\
\text { o }\end{array}$ & $\begin{array}{l}\text { Id_D } \\
\text { osen }\end{array}$ & $\mathbf{1}$ & $\mathbf{2}$ & $\mathbf{3}$ & $\mathbf{4}$ & $\begin{array}{l}\text { Core } \\
\text { Factor }\end{array}$ & $\begin{array}{l}\text { Secondary } \\
\text { Factor }\end{array}$ \\
\hline 1 & $\begin{array}{l}\text { CD00 } \\
1\end{array}$ & 4 & 4 & 4 & 4 & 4 & 4 \\
\hline 2 & $\begin{array}{l}\text { CD00 } \\
2\end{array}$ & 4 & 4 & 4 & 4 & 4 & 4 \\
\hline
\end{tabular}




\begin{tabular}{|l|l|l|l|l|l|l|l|}
3 & $\begin{array}{l}\text { CD00 } \\
3\end{array}$ & 5 & 5 & 5 & 5 & 5 & 5 \\
\hline 4 & $\begin{array}{l}\text { CD00 } \\
4\end{array}$ & 4 & 4 & 4 & 4 & 4 & 4 \\
\hline 5 & $\begin{array}{l}\text { CD00 } \\
5\end{array}$ & 5 & 5 & 5 & 5 & 5 & 5 \\
\hline
\end{tabular}

4. Aspek interview (wawancara) nilai core factor dan secondary factor

Perhitungan dengan terlebih dahulu menentukan sub aspek mana yang menjadi core factor dari aspek interview, sub aspek 1 , 3, 5, 6 dan 11 sub aspek sisanya akan menjadi secondary factor. Kemudian nilai core factor dan secondary factor tersebut dijumlahkan dan hasilnya bisa dilihat pada tabel berikut.

Tabel 12 Pengelompokan bobot nilai Gap interview (wawancara)

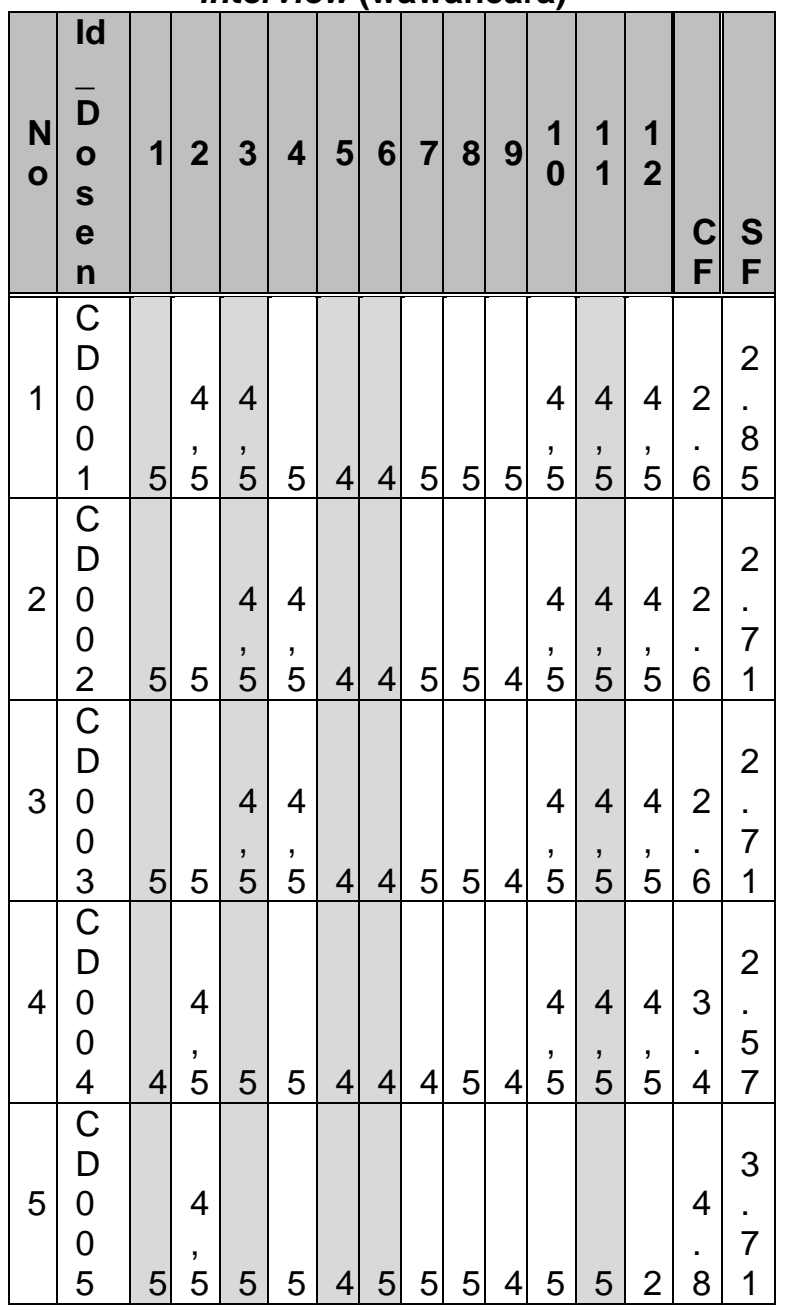

\subsection{Perhitungan nilai total}

Dari perhitungan setiap aspek yang diatas, berikutnya dihitung nilai total berdasarkan presentase dari core factor dan secondary factor yang diperkirakan berpengaruh terhadap kinerja tiap calon dosen tetap.

Adapun rumus yang digunakan :
Keterangan :

$$
N t=(x \%) N C F+(x \%) N S F
$$

NCF (aspek) : Nilai rata-rata core factor (aspek) NSF (aspek) : Niliai rata-rata secondary factor (aspek)

Nt (aspek) : Nilai total dari aspek

Untuk perhitungan nilai total dapat dilihat pada contoh dibawah ini :

1. Nilai total aspek tes potensi akademik Nt CD001 $=(60 \% \times 2)+(40 \% \times 3,5)=2,6$ Nt CD002 $=(60 \% \times 3,66)+(40 \% \times 4)=3,8$ Nt CD003 $=(60 \% \times 3,33)+(40 \% \times 4)=3,6$ $\mathrm{Nt} \mathrm{CD004}=(60 \% \times 3,33)+(40 \% \times 4)=3,6$ Nt CD005 $=(60 \% \times 2,33)+(40 \% \times 3)=2,6$

Tabel 13 Nilai core factor, secondary factor nilai total aspek tes potensi akademik

\begin{tabular}{|l|l|l|l|l|}
\hline $\begin{array}{l}\mathbf{N} \\
\text { o }\end{array}$ & $\begin{array}{l}\text { Id_Dos } \\
\text { en }\end{array}$ & $\begin{array}{l}\text { Core } \\
\text { Fact } \\
\text { or }\end{array}$ & $\begin{array}{l}\text { Secondary } \\
\text { Factor }\end{array}$ & $\begin{array}{l}\text { Nilai } \\
\text { Total }\end{array}$ \\
\hline 1 & CD001 & 2 & 3.5 & $\mathbf{2 . 6}$ \\
\hline 2 & CD002 & 3.66 & 4 & 3.8 \\
\hline 3 & CD003 & 3.33 & 4 & 3.6 \\
\hline 4 & CD004 & 3.33 & 4 & 3.6 \\
\hline 5 & CD005 & 2.33 & 3 & 2.6 \\
\hline
\end{tabular}

2. Nilai total aspek kemampuan membuka perkuliahan

Nt CD001 $=(60 \% \times 5)+(40 \% \times 0)=2,6$

Nt CD002 $=(60 \% \times 5)+(40 \% \times 0)=3,8$

Nt CD003 $=(60 \% \times 5)+(40 \% \times 2,5)=3,6$

Nt CD004 $=(60 \% \times 2,5)+(40 \% \times 2,5)=\mathbf{3}, 6$

Nt CD005 $=(60 \% \times 5)+(40 \% \times 2,5)=\mathbf{2 , 6}$

Tabel 14 Nilai core factor, secondary factor nilai total aspek kemampuan membuka perkuliahan.

\begin{tabular}{|l|l|l|l|l|}
\hline $\begin{array}{l}\mathbf{N} \\
\mathbf{0}\end{array}$ & $\begin{array}{l}\text { Id_do } \\
\text { sen }\end{array}$ & $\begin{array}{l}\text { Core } \\
\text { Factor }\end{array}$ & $\begin{array}{l}\text { Secondary } \\
\text { Factor }\end{array}$ & $\begin{array}{l}\text { Nilai } \\
\text { Total }\end{array}$ \\
\hline \hline 1 & $\begin{array}{l}\text { CD00 } \\
1\end{array}$ & 5 & 0 & 3 \\
\hline 2 & $\begin{array}{l}\text { CD00 } \\
2\end{array}$ & 5 & 0 & 3 \\
\hline 3 & $\begin{array}{l}\text { CD00 } \\
3\end{array}$ & 5 & 2.5 & 4 \\
\hline 4 & $\begin{array}{l}\text { CD00 } \\
4\end{array}$ & 2.5 & 2.5 & 2.5 \\
\hline 5 & $\begin{array}{l}\text { CD00 } \\
5\end{array}$ & 5 & 2.5 & 4 \\
\hline
\end{tabular}

\section{Nilai total aspek intelegensi umum}

Nt CD001 $=(60 \% \times 4)+(40 \% \times 4)=4$

Nt CD002 $=(60 \% \times 4)+(40 \% \times 4)=4$

Nt CD003 $=(60 \% \times 5)+(40 \% \times 5)=5$ 
Nt CD004 $=(60 \% \times 4)+(40 \% \times 4)=4$

Nt CD005 $=(60 \% \times 5)+(40 \% \times 5)=5$

Tabel 15 Nilai core factor, secondary factor nilai total aspek intelegensi umum.

\begin{tabular}{|l|l|l|l|l|}
\hline $\begin{array}{l}\text { N } \\
\mathbf{0}\end{array}$ & $\begin{array}{l}\text { Id_Do } \\
\text { sen }\end{array}$ & $\begin{array}{l}\text { Core } \\
\text { Factor }\end{array}$ & $\begin{array}{l}\text { Secondary } \\
\text { Factor }\end{array}$ & $\begin{array}{l}\text { Nilai } \\
\text { Total }\end{array}$ \\
\hline 1 & $\begin{array}{l}\text { CD00 } \\
1\end{array}$ & 4 & 4 & 4 \\
\hline 2 & $\begin{array}{l}\text { CD00 } \\
2\end{array}$ & 4 & 4 & 4 \\
\hline 3 & $\begin{array}{l}\text { CD00 } \\
3\end{array}$ & 5 & 5 & 5 \\
\hline 4 & $\begin{array}{l}\text { CD00 } \\
4\end{array}$ & 4 & 4 & 4 \\
\hline 5 & $\begin{array}{l}\text { CD00 } \\
5\end{array}$ & 5 & 5 & 5 \\
\hline
\end{tabular}

4. Nilai total aspek interview (wawancara) Nt CD001 $=(60 \% \times 2,6)+(40 \% \times 2,85)=\mathbf{2 , 7 0}$ Nt CD002 $=(60 \% \times 2,6)+(40 \% \times 2,71)=\mathbf{2 , 6 4}$ Nt CD003 $=(60 \% \times 2,6)+(40 \% \times 2,71)=\mathbf{2 , 6 4}$ $\mathrm{Nt} \mathrm{CD004}=(60 \% \times 3,4)+(40 \% \times 2,57)=\mathbf{3 . 0 6}$ $\mathrm{Nt} \mathrm{CD005}=(60 \% \times 4,8)+(40 \% \times 3,71)=\mathbf{4 , 3 6}$

Tabel 17 Nilai core factor, secondary factor nilai total aspek interview (wawancara)

\begin{tabular}{|l|l|l|l|l|}
\hline $\begin{array}{l}\mathbf{N} \\
\mathbf{0}\end{array}$ & $\begin{array}{l}\text { Id_Do } \\
\text { sen }\end{array}$ & $\begin{array}{l}\text { Core } \\
\text { Factor }\end{array}$ & $\begin{array}{l}\text { Secondary } \\
\text { Factor }\end{array}$ & $\begin{array}{l}\text { Nilai } \\
\text { Total }\end{array}$ \\
\hline 1 & $\begin{array}{l}\text { CD00 } \\
1\end{array}$ & 2.6 & 2.85 & 2.70 \\
\hline 2 & $\begin{array}{l}\text { CD00 } \\
2\end{array}$ & 2.6 & 2.71 & 2.64 \\
\hline 3 & $\begin{array}{l}\text { CD00 } \\
3\end{array}$ & 2.6 & 2.71 & 2.64 \\
\hline 4 & $\begin{array}{l}\text { CD00 } \\
4\end{array}$ & 3.4 & 2.57 & 3.06 \\
\hline 5 & $\begin{array}{l}\text { CD00 } \\
5\end{array}$ & 4.8 & 3.71 & 4.36 \\
\hline
\end{tabular}

\subsection{Perhitungan penentuan ranking}

Hasil dari proses profile matching adalah ranking dari kandidat yang yang akan menjadi dosen tetap. Penentuan ranking mengacu pada hasil perhitungan tertentu.

Rumus untuk mencari rangking :

$$
\text { Ranking : }=(x \%) N 1+(x \%) N 2+(x \%) N 3+
$$$$
(x \%) N 4
$$

Keterangan :

$\begin{array}{lll}\text { N1 } & \text { : Nilai tes potensi akademik } \\ \text { N2 } & : & \text { Niliai }\end{array}$

membukaperkuliahan

N3 : Nilai intelegensi umum

$\mathrm{N} 4 \quad$ : Nilai interview (wawancara)

$(\mathrm{x}) \% \quad$ : Nilai persen yang diinputkan
Contoh dari rumus untuk perhitungan ranking diatas, perhatikan hasil akhir dari kode calon dosen dengan nilai persen $=30 \%, 20 \%, 10 \%, 40 \%$ sebagai berikut :

Ranking CD001 $=(30 \% \times 2,6)+(20 \% \times 3)+(10 \%$ $\times 4)+(40 \% \times 2,7)$

$=0,78+0,6+0,4+1,08=\mathbf{2 , 8 6}$

Ranking CD002 $=(30 \% \times 3,8)+(20 \% \times 3)+(10 \%$ $\times 4)+(40 \% \times 2,64)$

$=1,14+0,6+0,1+0,4+1,056=\mathbf{3 , 1 9 6}$

Ranking CD003 $=(30 \% \times 3,6)+(20 \% \times 4)+(10 \%$ $\times 5)+(40 \% \times 2,64)$

$=1,08+0,8+0,5+1,056=3,436$

Ranking CD004 $=(30 \% \times 3,6)+(20 \% \times 2,5)+(10 \%$ $\times 4)+(40 \% \times 3.06)$

$=1.08+0.5+0,4+1,224=3,204$

Ranking CD005 $=(30 \% \times 2,6)+(20 \% \times 4)+(10 \%$ $x 5)+(40 \% \times 4,36)$

$=0.78+0.8+0.5+1,744=3,824$

Tabel 18 Hasil akhir proses profile matching

\begin{tabular}{|l|l|l|l|l|l|l|}
\hline $\begin{array}{l}\mathbf{N} \\
\mathbf{0}\end{array}$ & $\begin{array}{l}\text { Id_Do } \\
\text { sen }\end{array}$ & $\begin{array}{l}\mathbf{N 1} \\
\mathbf{2 0} \%\end{array}$ & $\begin{array}{l}\mathbf{N 2} \\
\mathbf{5} \%\end{array}$ & $\begin{array}{l}\mathbf{N 3} \\
\mathbf{1 0} \%\end{array}$ & $\begin{array}{l}\mathbf{N 4} \\
\mathbf{1 5} \%\end{array}$ & $\begin{array}{l}\text { Rank } \\
\text { ing }\end{array}$ \\
\hline \hline 1 & $\begin{array}{l}\text { CD00 } \\
1\end{array}$ & 2.6 & 3 & 4 & 2,7 & 2,86 \\
\hline 2 & $\begin{array}{l}\text { CD00 } \\
2\end{array}$ & 3.8 & 3 & 4 & 2,64 & 3,196 \\
\hline 3 & $\begin{array}{l}\text { CD00 } \\
3\end{array}$ & 3.6 & 4 & 5 & 2,64 & 3,436 \\
\hline & $\begin{array}{l}\text { CD00 } \\
4\end{array}$ & 3.6 & 2.5 & 4 & 3,06 & 3,204 \\
\hline & $\begin{array}{l}\text { CD00 } \\
5\end{array}$ & 2.6 & 4 & 5 & 4,36 & 3,824 \\
\hline
\end{tabular}

Setelah setiap kandidat calon dosen tetap mendapatkan hasil akhir seperti contoh pada tabel diatas, maka bias ditentukan peringkat atau ranking dari kandidat berdasarkan pada semakin besar nilai hasil akhir sehingga semakin bessar pula kesempatan kandidat calon dosen tetap untuk menjadi dosen tetap, begitu pula sebaliknya.

\section{Kesimpulan}

Dari hasil perhitungan diatas maka didapatkan bahwa kandidat calon dosen tetap yang ditentukan dengan metode profil matching adalah calon dosen tetap dengan kode CD005 yang memiliki nilai sebesar 3,824.

6. Referensi

[1] Ahmad Arifin, Joko Dwi Raharjo, Andriyan Darmadi.,2015, Sistem Penunjang Keputusan Penerimaan Dosen Dengan Metode Analytic Hierarchy Process. Jurnal Sisfotek Global, ISSN : 2088 - 1762 Vol.5 No.1 Maret 2015

[2] Bety Wulan Sari., 2015, Perbandingan Metode Profile Matching dan Simple Additive 
Weighting pada Penentuan Jurusan Kelas $X$ SMA N 2 NGAGLIK. Jurnal IImiah DASI Vol.16 No.1 Maret 2015. ISSN : 1411-3101

[3] David B. Meinert, Donald L. Davis., Human Resource Decision Support System (HRDSS) Intergrating Decision Support and Human Resource Infprmations System. Information Resource Management Journal Volume.2 No.1 Winter 1989.

[4] Deepika Kumari Chack., Decision Support System For Human Resource Management Of The Organization, International Journal of Management Research and Business Strategy. ISSN 2319-345X Volume. 2 No. 3 July 2013.

[5] Edianto Berutu.,2015, Sistem Pendukung Keputusan Pengangkatan Karyawan Tetap Dengan Metode Analytic Hierarchy Process (AHP) Pada PT. Perkebunan Lembah Bhakti Propinsi NAD Kab. Aceh Singkil. Pelita Informatika Budi Darma, Volume : IX, Nomor.3 April 2015. ISSN : $2301-9425$.

[6] Edi Faizal,.2014, Implementasi Metode Profile Matching untuk Penentuan Penerimaan Usulan Penelitian Internal Dosen STMIK EI Rahma, Journal Speed - Sentra Penelitian Enginering dan Edukasi - Volume. 6 No.1.2014 speed.web.id

[7] EE-Peng Lim, Hsinchun Chen, Guoqing Chen., 2013. Business Intelligence And Analytic : Research Directions. ACM Transsactions on Management Information System, Vol. 3 No. 4 Aticle 17, Publication date. January 2013.

[8] Friyadhie.,2016, Penggunaan Metode Profile Matching Untuk Sistem Penunjang Keputusan Kenaikan Jabatan Pada Instansi Pemerintah, Paradigma Vol. XVIII No.2 September 2016.

[9] Gunawan, Fandi Halim, Afriandri Raimon Perdana Purba.,2016, Pengembangan SPK Penerimaan Karyawan dengan Menggunakan Profile Matching, Studi Kasus: PT.X. Seminar Nasional Teknologi Informasi dan Multimedia 2016 (STMIK AMIKOM Yogyakarta 6-7 Februari 2016). ISSN: 2302 -3805 .
[10] Hsu-Shih Shih, Liang- Chih Huang, HuanJyh Shyur.,2005, Recruitment and Selection Process Through an Effective GDSS. An International Journal Computer and Mathematics with Applications 50 (2005) 1543 $-1558$. www.elsevier.com/locate/camwa.

[11] I Dewa Made Adi Baskara Joni, Anak Agung Gede Bagus Iriana.,2014, Sistem Pendukung Keputusan Seleksi Penerimaan Dosen Dengan Metode Fuzzy -AHP. Jurnal IImiah Nero Vol. 1 No.2

[12] Muh. Bahri Izatu, Nur Fajriah Muchlis, L.M. Tajidun., Desember 2016, Perbandingan Metode Profile Matching dan Promethee dalam Menentukan Siswa Layak Penerima Beasiswa Kurang Mampu di SMK Kelautan dan Perikanan Kendari, semanTIK. Volume. 2 No. 2, ISSN : 2502 - 8928 (Online)

[13] Ripto Mukti Wibowo, Adhistya Erna Permanasari, Indriana Hidayah., 2015, Penerapan Maetode Profile Matching untuk Aplikasi Multi Criteria Decision Making, Seminar Nasional Teknologi Informasi dan Multimedia (STMIK AMIKOM Yogyakarta 6-8 Februari 2015). ISSN : 2302-3805.

[14] Subagyo, Joko. (2004). Metode Penelitian Dalam Teori Dan Praktek. Jakarta : PT.

Rineka Cipta.

[15] Wiji Setianingsih, Decision Support System Menggunakan Metode Profile Matching (2013).

[16] Xiaoqian Sun, Yongehang Li., 2010, An Intelligent Multi-Criteria Decision Support System for System Design. 10 $10^{\text {th }}$ AIAA Aviation Technology, Integration, and Opertions (ATIO) Conference 13-15 September 2010, Fort Worth, Texas. AIAA. 2010 - 9222.

[17] Zamralita.,2017, Gambaran Keterikatan Kerja pada Dosen Tetap Di Tinjau Dari Karakteristik Personal, Jurnal Muara IImu Sosial, Humaninora dan Seni Volume. 1 No. 1 April 2017. Halaman. $338-345$. ISSN . 2579 - 6348. ISSN-L. 2579-6356 